\title{
ABOUT THE RELATIONSHIP OF POLYSEMY, SYNONYMY, PARONYMY AND VARIANTS AT THE LEVEL OF WORDS AS A COMPLETE UNIT OF DERIVATOLOGY
}

\section{Shepel Yu. A.}

\section{INTRODUCTION}

The description of the polysemy of lexicon units (and, first of all, words) is one of the most difficult tasks of lexical semantics. The main issues of the scientific description of the polysemy of lexical units are associated, first of all, with the definition of the boundaries of this category. Basic theoretical tasks in this direction can be formulated as follows: a) the distinction between homonymy and polysemy (that is, the establishment of boundaries in which it is legitimate to talk about different meanings of the same word, in contrast to cases in which we have different words that coincide in form); b) the distinction between polysemy and monosemy (setting the limit to which the difference in specific uses of a word can be considered as contextualized variation within one meaning, in contrast to cases when the next use of a word should be described as the realization of another meaning).

Since synonymy is one of the most fundamental concepts of linguistics, researchers consider it to be an indefinable and primary concept even in relation to the concept of meaning: meaning is what is common in synonymous statements. Synonymy is not only a relationship between words, it pervades the entire language. For example, the suffixes are synonymous =mель и =щик (водитель, сварщик). They have the same meaning "one who professionally does something". Units of different levels of the language can also be synonymous, for example, the word слишком and prefix пере- (пересолить, перестараться, переперчить, nереговорить). However, speaking of synonymy, they declare series of synonymous words.

There are several interpretations of the term paronymy. Paronyms in the "narrow" sense are closely related words. In the "broad" sense, paronyms are defined as words that sound similar to some extent, but have different meanings. Sometimes the phenomenon traditionally called paronomasia is referred to as paronymy - a stylistic device in which words that sound similar, both related and unrelated, are deliberately brought together.

We consider variability as inconsistencies in appearance, in the form of linguistic signs that have the same meaning. From a sociolinguistic point of 
view, the phenomenon of variability deserves special attention, since different language variants can be used depending on social differences between native speakers, on differences in the conditions of verbal communication.

The relevance of the topic lies in the fact that the concepts of variability, polysemy, synonymy, paronymy now increasingly penetrate the research process in linguistics, many related issues are still insufficiently studied. The aim of the research is to describe the concepts of polysemy, synonymy and paronymy in relation to variability. The object of the description is the phenomena of polysemy, synonymy and paronymy, the subject is their relationship with the phenomenon of variability in the Russian language.

\section{Polysemy and issues of its consideration}

In those linguistic traditions for which the concept of a word is central, polysemy is usually spoken about in relation to words, and since the European linguistic tradition is word-centric, we will consider the basic problems of studying polysemy precisely on the basis of the polysemy of words (lexical polysemy). It is known that any linguistic signs are characterized by polysemy: lexicon units are less and more than a word (that is, morphemes - both root and service ones - and phraseological units of various types), as well as grammemes, models of syntactic constructions, intonation contours, etc.

In inflected languages, polysemy is observed in many affixes. For example, the Russian prefix npo- has such opposed meanings as ' pass by ' $/$ 'мимо' (пройти мимо ресторана) and 'completely, from top to bottom' / 'полностью, сверху донизу' (пробить стену насквозь). This example demonstrates the relativity of the criteria for highlighting values. If, in the metalanguage description of individual meanings, one is guided by the highest level of generalization, then a large number of semantic variants can be combined within one meaning. So, if one of the prefix values npoformulated as 'completely', then there are such cases of the implementation of this prefix as просверлить, прожечь, прожарить, прокутить, промотать, проесть, проиграть, пропить. If we choose more specific formulations, then within this group, different subgroups can be distinguished: 'through and through' (просверлить, пробить, прожечь), 'thoroughly' (прожарить, промыть, просеять) and 'use up completely' (прокутить, промотать, проесть, пропить, проиграть).

The "correctness" of one way or another of description will largely depend on the correspondence to the tasks set. Thus, the presence of more than one meaning in a linguistic sign is an ontological property of the sign. The plane of expression and the plane of the content of a linguistic sign are not in one-toone, but in asymmetric relations, from which it objectively follows that one 
signifier tends to express more than one signified and vice versa. Determining the boundaries of the category of ambiguity does not lend itself to clear operation. A significant amount of research has been devoted to the search for criteria that make it possible to distinguish between polysemy and homonymy, on the one hand, and polysemy and monosemy, on the other hand. However, any of the proposed criteria, taken separately, is only relative.

Since the semantic description of lexical units is a theoretical construct obtained as a result of an analysis carried out for one purpose or another, it is clear that the same unit can be described in different ways. The absence of common features in the interpretation does not mean that they cannot be distinguished in the corresponding semantic structures. The allocation of common features as a basis for establishing polysemy sometimes causes discussion, because not only their potential presence is important, but also their status in terms of the content of the unit that they describe. In particular, it can be etymologically distinguished features that are not included in the meaning of the word at the synchronous level. In this case, they speak only of some potentially significant connection at the metaphorical level.

\section{Questions of the definition of paronyms and their stylistic differentiation}

As noted above, paronyms are usually understood as words with a similar morphemic structure and different content ${ }^{1}$. In a broad sense, paronyms mean all sorts of similar sounding words. In a narrow sense, only semantically close single-root words are called paronyms ${ }^{2}$.

According to the author of the "Dictionary of Russian paronyms" Yu. A. Belchikov and the author of the "Explanatory Dictionary of Russian Paronyms" V. I. Krasnykh, paronyms should include single-root words that belong to the same part of speech, having sound similarity, but differing in their meanings (such as гневныц because in paronyms their sound similarity is not accidental, but is a consequence of the presence of word-formation and semantic connections of these linguistic units. This point of view appeals to us much more, since we

${ }^{1}$ Вишнякова О.В. Паронимия в русском языке [Текст]. Москва : Рус. язык, 1984. $382 \mathrm{c}$.

2 Вишнякова О.В. Паронимия в русском языке [Текст]. Москва : Рус. язык, 1984. 382 с.; Воркачев С.Г. Из истории слов: лингвокультурный концепт [Текст]. Новое в когнитивной лингвистике. Кемерово : Изд-во КемГУ, 2006. Ст. 3-14.

${ }^{3}$ Бельчиков Ю.А. Словарь паронимов русского языка [Текст] / Ю.А. Бельчиков, М.С. Панюшева. Москва : АСТ; Астрель, 2004. 458 с.; Красных В.И. Толковый словарь паронимов русского языка [Текст]. Москва : АСТ; Астрель, 2003. 592 с. 
consider polysemy, synonymy and paronymy at the level of variability of word formation, in particular at the level of word-formation series.

In scientific research, to characterize the binomial groups of paronyms, the terms paronymic series or paronymic opposition are used, which are very acceptable for our research ${ }^{4}$.

Developed within the framework of phonology (it is no coincidence that in the dictionary of linguistic terms by O.S. Akhmanova ${ }^{5}$ it is interpreted only from the standpoint of phonology), the concept of opposition in modern scientific research is used as a general linguistic one, applicable to units of different levels of language.

For the study of paronymy, the point of view of N.S Trubetskoy is important that "opposition (opposition) presupposes not only features that differ from each other members of the opposition, but also features that are

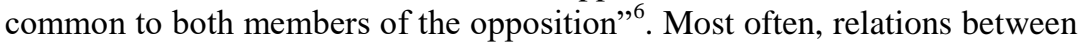
members of the opposition are considered on the basis of marking unmarking, where one of the opposition members is marked, and the other is unmarked. This kind of opposition is traditionally called a privative opposition .

Equipollent opposition is less significant (including in the study of paronyms), which involves the opposition of members according to one differential feature ${ }^{7}$. For example: aдресат - адресант, аэробный анаэробньй, импорт - экспорт, etc.

When systematically considering the phenomenon of paronymy, it is necessary to take into account the functional and stylistic characteristics of the text.

When systematically considering the phenomenon of paronymy, it is necessary to take into account the functional and stylistic characteristics of the text. With regard to texts that are classified as official-business and scientific styles, that is, to texts with a rigid structure, which are characterized by a striving for accuracy, consistency, unambiguity, where the competence of the text creators makes it possible to exclude elementary erroneous substitutions, it is desirable to use a narrow understanding of paronyms. In

${ }^{4}$ Веракша Т.В. Лингвистическая природа паронимов русского языка : дис. ... д-ра филол. наук [Текст]: 10.02.01. Санкт-Петербург. 2000. 343 с.

5 Ахманова О.С. Словарь лингвистических терминов [Текст]. Москва : Либриком, 2010. $576 \mathrm{c}$.

${ }^{6}$ Трубецкой Н.С. Основы фонологии / Пер. с нем. А. А. Холодовича; Под ред. С.Д. Кацнельсона ; Послесл. А.А. Реформатского; Вступ. ст. Л.А. Касаткина. 2-е изд. Москва : Аспект-Пресс, 2000. Ст. 72.

7 Лингвистический энциклопедический словарь [Текст] / под ред. В.Н. Ярцевой. Москва : Большая российская энциклопедия, 2002. Ст. 348. 
these styles, the main problem for differentiation is represented by incomplete paronyms, that is, words, the semantic delimitation of the scope of meanings of which in a natural language is not completely completed.

When two words similar in meaning and morphemic structure are used in the text of a scientific style, there is a tendency to differentiate their meanings. According to his point of view, S.G. Vorkachev, the paronymic opposition is an etymological doublet and paronyms striving to gain and acquire independent meaning. "If mentality is a way of seeing the world in general, then mentality is a set of specific cognitive, emotive and behavioral stereotypes of a nation"

in a scientific style, associated with the possibility of profiling with their help conceptual differences based on formal vocabulary discrepancies. The independent names that have arisen as a result of semantic differentiation require increased attention and metalinguistic reflection, cf. frequently observed interchange of terms лингвокультурный - лингвокультурологический, варьирование - вариантность, топонимия топонимика, E.I. Golovanova writes about the widespread tendency to distinguish between consonant words in scientific speech ${ }^{9}$. And this is convincingly confirmed by scientific publications of recent years.

Certain restrictions are imposed on the process of functioning of consonant linguistic units, especially in a scientific style, associated with the possibility of profiling with their help conceptual differences based on formal vocabulary discrepancies. The independent names that have arisen as a result of semantic differentiation require increased attention and metalinguistic reflection, cf. frequently observed interchange of terms лингвокультурный - лингвокультурологический, варьирование вариантность, топонимия - топонимика, etc.

Paronymy is widespread in many texts of different content and industry, as evidenced by the Internet.

In the official business style, some lexemes may be used in a different sense. For example, in the meaning of "affordable housing" (low cost and cost of housing), they use the term экономический instead of экономичный in combination with economy class housing. This can be explained by the fact that the formal business style is characterized by the use of fixed expressions that do not allow replacement of components. Thus, a change in the

${ }^{8}$ Воркачев С.Г. Из истории слов: лингвокультурный концепт [Текст]. Новое в когнитивной лингвистике. Кемерово : Изд-во КемГУ, 2006. Ст. 6-7.

${ }^{9}$ Голованова Е.И. Паронимия в научном тексте как проблема соотношения языковой формы и содержания [Текст]. Гуманитарный вектор. 2012. № 4 (32). Ст. 28-33. 
composition of the combination "economy class housing" of the adjective экономический to экономичный would be considered as mistake.

Journalistic style. Within this style, we observe the functioning of both full and incomplete paronyms. Moreover, paired lexemes, which in scientific and official-business texts are perceived as paronymic oppositions, in publicistic texts can function as synonyms or variants. For example, the adjective прозаический from the 1-st meaning forms phrases that name concepts related to prose as a type of literary creation (scientific style). In other meanings, prosaic and prosaic act as synonyms, forming the same type of phrases ${ }^{10}$. Among the reasons for not distinguishing paronyms in a publicistic text are the following:

1) disregard for the accuracy of the statement, where preference is given to the information component;

2) to create a comic effect («Вот ответил бы архетипичнылй Овен! А народ требует любовный прогноз, и не какой-то личный, а на неделю! Что может измениться у архетипических Овнов и их архетипических партнерш-Весов или любимых Львов за неделю?» ${ }^{11}$;

3) action function, for example: "Сливки с агитационных кампаний оппонентов Путина снимет кандидат “против всех”. Архетипические черты русского человека могут сделать несостоятельными прогнозы» ${ }^{12}$.

There are many examples of the erroneous use of consonant lexemes in the journalistic style. According to H.M. Lazutkina, mixing of paronyms is a common mistake in the media ${ }^{13}$. She uses as examples such paronymic pairs as заболеваемость - заболевание («растет число заболеваемостей гриппом»), фермерство - фермеры («начался отток фермерства»), управляемость - управление («чтобы не потерять управляемость обществом») рассыпчатая пудра - рассыпная пудра, экономное экономичное строительство (вместо экономичное строительство), etc. Or улучшается криминогенная обстановка (вместо криминальная), следует повысить противопожсарную безопасность (вместо пожарную);

4) to emphasize the main meaning of the statement, for example: "Грозят или угрожают?", - on the economic blockade of Russia by Western countries after the annexation of Crimea. Subtle differences in the

${ }^{10}$ Бельчиков Ю.А. Словарь паронимов русского языка [Текст] / Ю.А. Бельчиков, М.С. Панюшева. Москва : АСТ; Астрель, 2004. 458 с.

${ }^{11}$ URL: http://www.ratsen.narod.ru/programm.html.

${ }^{12}$ URL: http://www.press.ru-vector.com/2009/11/01/7828/.

13 Лазуткина Е.M. Публицистический стиль: новые черты [Текст]. Москва : Элпис, 2008. Ст. 36.

${ }^{14}$ Южноуральская панорама. № 36, 18.03.2014 
semantics of cognate words help to draw the attention of readers to a journalistic text.

Conversational style. In it we observe a massive use of paronyms, the reasons for which are associated with unpreparedness, spontaneity, reliance on non-verbal means of speech. For example: подпись - роспись, различать - отличать (различие - отличие), главный - заглавный, познакомиться - ознакомиться, неприятный - нелицеприятный, представить - предоставить, патронаж-патронат, etc.

Thus, paronyms as words that are similar in sound and not identical in meaning are a universal phenomenon: they are represented in all styles and functional systems and subsystems of the language. Phenomena based on the existence of paronyms make it possible to talk about the systemic and asystemic nature of paronymic convergence (attraction) in the language and consciousness of people.

\section{The relation of paronyms to homonyms, synonyms, antonyms}

When studying paronyms, the question arises about their relationship to other lexical categories - homonyms, synonyms and antonyms. So, some scientists consider paronymy as a kind of homonymy, and paronyms, therefore, as "pseudo-names", indicating their formal closeness. However, with homonymy, there is a complete coincidence in the pronunciation of words that are different in meaning, and paronymic forms have some differences not only in pronunciation, but also in spelling. In addition, the semantic similarity of paronyms is explained etymologically: initially they had a common root. And the similarity of homonymic words is purely external, accidental (except for those cases when homonymy develops as a result of the decay of the meanings of a polysemantic word).

Paronyms must also be distinguished from synonyms, although sometimes this is difficult to do. When distinguishing between these phenomena, it should be borne in mind that the discrepancy in the meanings of paronyms is usually so significant that replacing one of them with another is impossible. Mixing paronyms leads to gross lexical errors: "Мать одела (it is necessary надела) на ребенка пальто"; "В вестибюле гостиниць сидели командировочные”" (it is necessary командированные)".

Synonyms are often used interchangeably. With all the originality of semantic structures, they provide the author with the right to a wide choice of the most suitable word in meaning, not excluding options for synonymous replacement. At the same time, cases of transition of paronyms to synonyms are known. So, relatively recently, the word humbled meant "to become meek, obedient, humble"; its use in the meaning of "reconcile" was considered unacceptable. However, in colloquial speech, this word is increasingly used in the meaning of "getting used to, to come to terms with something": 
смириться с бедностью, смириться $с$ недостатками. Modern explanatory dictionaries of the Russian language mark this meaning as the main one. Thus, the former paronyms, as a result of their mixing in speech, can converge and, in the end, turn into synonyms. However, it should be borne in mind that the interchangeability of recent paronyms is permissible only if the new meaning developed by them is fixed in the language.

The semantic difference of paronyms does not extend, as a rule, to the extreme opposite, that is, paronyms do not enter into antonymic relations. They can only be contrasted in context: «Долг, а не должнность»; «Служсние, а не служба» (headlines of newspaper articles). However, this opposition of paronyms does not affect their systemic connections in the vocabulary and is of an occasional nature.

\section{Variation (variability), invariant and variant}

Variation (from Latin varians, genitive variantis - changing) (variability) - 1) the idea of different ways of expressing a linguistic essence as its modification, variety, or as a deviation from some norm (for example, discrepancies in different lists of the same monument); 2) a term characterizing the way of existence and functioning of language units and the language system as a whole.

Variability is a fundamental property of the language system and the functioning of all units of the language. It is characterized using the concepts "variant", "invariant", "variation". At the first understanding of variability, only the terms "variant" and "variation" are used; what is being modified is understood as a certain sample, standard or norm, and a variant is understood as a modification of this norm or a deviation from it. In the second understanding, the term "invariant" is introduced and the opposition is variant - invariant.

By variants we mean different manifestations of that very phenomenon, for example, a modification of the same unit, which, with all changes, remains by itself.

An invariant is an abstract designation of that very unit in abstraction from its specific modifications - options. The second understanding of the concept of variability is a development and deepening of the first, it introduces into linguistics the general principles of the theory of variance invariance.

The concept of an invariant reflects the general properties of a class of objects formed by variants. The invariant itself does not exist as a separate object, it is not a representative of a class, not a standard, not a "model variant". Invariant is an abbreviated name for a class of relatively homogeneous objects. As a name, the invariant has a verbal form of existence. Each variant-object belonging to a specific variant series has 
invariant properties that are inherent in each member of this series, and can be evaluated as a "representative" of this invariant. The concept of an invariant is a classification tool for ordering linguistic material.

All language units are variable, that is, they are presented in the form of many options. The variability of language units reveals the variant-invariant structure of the entire language system.

Invariants, being the result of understanding and combining the objective common properties of different series of concrete units, can be of varying degrees of abstractness. So, the word form "lamp" is a specific instancevariant (allolex, lexa) of the lexeme "raмna" (invariant of the 1st degree of abstractness), an instance-variant of a noun (2nd degree), an instancevariant of a word in general ( $3 r d$ degree).

According to the principle of linearity of speech, only one variant of a linguistic unit can be placed at one place in the speech chain. Therefore, speech by its nature is variant. The variability of language units manifests itself in different ways at different levels of the language system. At the levels of two-sided units, the sound for the derivation of invariants is not relevant, but the meaning and function are essential. The most difficult is the question of the variability of the meanings of linguistic units. The value of any unit is in itself invariant and serves as the basis for combining different instances of the unit with this value into a variant class. Different meanings of the same word do not vary, but are accumulated in the word. Variants of the same meaning of a word with respect to some invariant, apparently, can be talked about when in a series of semantically different units we regularly find "the same meaning", for example, the same lexical and general grammatical (part of speech) meaning in numerous word forms of the word.

\section{The influence of polysemy on the semantic ratio of single-root multi-affix derivatives of words in the derivational series of adjectives}

A significant number of single-root words belonging to different derivational series and entering synonymic and paronymic relations are polysemantic words. Semantic links are possible between polysemantic words according to one of the meanings, that is, individual lexical-semantic variants (hereinafter - LSV) of polysemantic words can enter synonymous links ${ }^{15}$. When the individual meanings of polysemous words enter synonymous relationships, the others reveal paronymic relationships. Paronymic relations of individual meanings of polysemantic words can be illustrated by the example of adjectives related to word-formation rows on

${ }^{15}$ Бережан С.Г. Семантическая эквивалентность лексических единиц. Кишинев : Штиинца, 1973.372 с. 


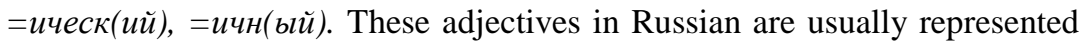
by correlative pairs академический - академичный, автоматический автоматичный, аллегорический - аллегоричный, демократический демократичныій, иронический - ироничный, лирический - лиричныій, методический - методичный, исторический - историчныгй, мелодический - мелодичный, метафизический - метафизичный, неврастенический - неврастеничный, органический - органичный, пластический - пластичный, полемический - полемичный, схематический - схематичный, технический - техничный, трагический - трагичный, экономический - экономичныгй, юмористический - юмористичный, этический - этичный and others (54 pairs in total). Complex relations between pairs of adjectives of derivational rows on $=и ч е с к(и \check{u}),=и ч н($ biü) are explained by the polysemy of many adjectives of the derivational row on =ическ $(u \check{u})$, which, developing qualitative meanings, are synonymized with adjectives of the derivational row on $=и ч н(ь и ̆)$. For example, the word методичный is explained as "the same as methodical in the second sense", that is, the adjective методичный coincides with the adjective методический in a qualitative sense. We observe the same relationship with other couples, for example: антагонистический - антагонистичный, демократический демократичный, драматический - драматичный, лирический лиричный, мелодический - мелодичный, метафизический метафизичный, мифический - мифичный, мистический - мистичный, патриотический - патриотичныгй, прозаический - прозаичный, поэтический - поэтичный, психологический - психологичный, ритмический - ритмичный, полемический - полемичный, иронический ироничный, симптоматический - симптоматичный, статический статичный, схематический-схематичный, трагический-трагичный, феерический - фееричный, цинический - циничный, флегматический флегматичный, романтический - романтичный, фантастический фантастичный.

To differentiate word-formation paronymy and synonymy, we use the idea of the logical relation of homosemous units with synonymy: complete coincidence and inclusion (=absolute synonyms), intersection (=partial synonyms), complete mismatch (=different words). We distinguish between lexical and derivational synonyms and paronyms. Lexical paronyms are words of different derivational nests, formed from homonymous roots or one root. The lexical meanings of the components of a paronymic pair are necessarily delimited, let us compare: земляной - земной, обидный обидчивый, иветной - цветовой, просительный - просительский, разборочный - разборчивый, спасательный - спасательский, непроницаемый - непроницательный. 
Partial synonyms $\mathrm{V}$ paronyms are single-root words that are close in meaning, located in one word-formation nest, but in different wordformation series. For partial paronymy $V$ synonymy, the synonymy of the stages of derivation is inherent, compare: покупательный покупательский (купить - покупать - покупательный / купить покупать - покупатель - покупательский), малахитный малахитовый (малахит - малахитный, малахитовый), раскольнический - раскольничий (колоть - расколоть - раскольник раскольнический, раскольничий), мелодический - мелодичный (мелодия-мелодический, мелодичный), прозаический - прозаичный (проза - прозаический, прозаичный), сладкий - сладостный.

For synonyms that are formed at one step of derivation, the synonymy of affixes is characteristic, cf.: нераздельный - неразделимый, романтический - романтичный, ремесленнический - ремесленный, наследный-наследственный, дарёный - даровой, гневливый-гневный.

A separate issue for study is the vocabulary "paronymic pairs" characterized by the presence of polysemic parallelism in words with lexical polysemy. Partial synonymy $\vee$ paronymy is most often preserved at the level of the LSV of polysemantic words. Preservation of semantic links between LSV enables lexicographers to interpret identically pairs of words cited in dictionaries as paronyms. Such pairs of words are often considered as derivational variants. Distinguishing word-formative synonyms and variants is a separate issue that requires special research from the standpoint of the semantic structure of word-formative entries and the intersection of wordformative rows with them. Synonyms $\vee$ paronyms formed on the basis of one / several meanings of homonymous words like публицистический 1,2 and публицистичный 1,2 .

An attempt to comprehend paronymy and show paronyms in their connections with other linguistic units, to determine their characteristic features was undertaken by Ukrainian linguists D.G. Grinchishin and A.A. Serbenskaya ${ }^{16}$. Their analysis is based on the concept of "semantic field". In the dictionary, the authors distinguish between full and incomplete paronyms. The researchers note that "the ability to completely diverge in meanings is shown by full paronyms (they are also called real, absolute or maximum). However, certain paronymic relations can be entered by words that are close in sound terms (most often single-rooted), in which the process of delimitation in meaning has not been fully completed: in some meanings they diverge, in others they come closer, entering further into synonymous

${ }^{16}$ Грінчишин Д.Г., Сербенська О.А. Словник паронімів української мови. Київ : Рад. школа, 1986. 222 с. 
connections. These are incomplete paronyms" ${ }^{\prime 17}$. The authors of the dictionary classify incomplete paronyms as partial synonyms.

The basis for identifying paronyms among single-root different affix formations is the semantic opposition of words of one part of speech, formed from one root.

Among the lexical paronyms of adjectives, suffix formations are widely represented: хваткий // хватский, старательный // старательский, разборочный // разборчивый, обличительный // обличительский, опытнический // опытный, наёмнический // наёмный, мучительный // мучительский, наблюдательный // наблюдательский, просветительный // просветительский, неорганический // неорганичный, ароматический // ароматичный, еtс.

Paronymy, in my opinion, is a consequence of word-formation processes and the intersection of semantic fields of single-root multi-affix derivatives of word-formation rows. Paronyms are characterized by a mismatch (almost complete) of the spheres of lexical compatibility, which excludes the use of one paronymic lexeme instead of another in the same context. With a possible coincidence of the lexical compatibility of paronyms (compare: реальный взгляд // реалистическое искусство), we observe a discrepancy between the spheres of meaningful identification, which also excludes the interchangeability of lexemes of the same paronymic pair.

Single-root words become paronyms when they acquire the greatest independence, the greatest differentiation in their lexical meaning, compare: солярный // соляровый, командированный // командировочный, склочнический // склочныій, эстетный // эстетский, строительный // строительский, просительный // просительский, прожигательный // прожигательский, луковичный // луковый, непроницаемый // непроницательный, поручительный // поручительский, отходный // отходчивый, проповеднический // проповедничий, подрядный // подрядческий, гусачий // гусячий, мучительный // мучительский, наёмничий // наёмный, опытнический // опьтный, старательный // старательский, спасательный // спасительный // спасательский, обличительный // обличительский, разборочный // разборчивый. Therefore, it is impossible to refer to absolute paronyms all single-root words in which one word indicates a sign, and the other - to a part of this sign in a different quality and quantity, like мучной - мучнистый, волосатыци - волосастый, носатый - носастый and etc.

${ }^{17}$ Грінчишин Д.Г., Сербенська О.А. Словник паронімів української мови. Київ : Рад. школа, 1986. Ст. 4. 
To distinguish between paronyms and synonyms, it is necessary to find features that define each of these two linguistic phenomena in the system of single-root formations. The common things that create the preconditions for mixing single-root different affix words in the process of their use are: on the semantic level - the proximity of a large number of words; at the morphological level - the commonness of the root morpheme and belonging to one part of speech; at the phonetic level, the similarity of the sound envelopes of words. Therefore, from lexical point of view, synonyms are single-root words if they express one concept, have the same volume, the same lexical valence, belong to the same part of speech, are stylistically diverse, and paronyms are words that express different concepts, the differentiating element of the meaning of which indicates an incomplete coincidence of the semantic volumes of the members of the row, which turns them into separate lexical units and manifests itself in the specifics of their compatibility with other words when they function in the language.

Identifying the volumes of the meaning of single-root formations, we observe a gap in the semantic content of both synonyms and paronyms. However, synonyms are characterized by a slight semantic shift and, in most cases, stylistic diversity. For paronyms, the gap in semantic content is more significant.

Since in our study we are talking about single-root words of different derivational series, the principle of commonness and difference should be the basis for distinguishing between synonyms and paronyms.

Single-root synonyms and paronyms have a common semantic center. They are semantically linked by semantic motivation and the top of the word-formation nest. But the two words that make up a paronymic pair have a different subject-logical basis, which causes their different lexical compatibility. The selection of synonyms for each of them can serve as a check for the gap in the semantics of two, at least, derived words from monosemous roots ${ }^{18}$. So, in pairs of adjectives прилагательных главный // заглавный, незаменимый // незаменный, несльшимый // неслышный, гнилой // гнилостный, дождевой // дождливый, духовный // духовой, дыммный // дымовой, дарёный // даровой, грозный // грозовой, громкий // громовой, водный // водяной, шумный // шумовой, шелковистый // шёлковый, каменистый // каменный, лобный // лобовой, зернистый // зерновой, горделивый // гордый, гневливый // гневный the replacement of one component with another is a sign of paronymic attraction (semantic syncretism) based on the proximity of the sound of the elements of each pair

${ }^{18}$ Русская грамматика : в 2 т. Москва : Наука, 1980. Т. 1 : Фонетика. Фонология. Ударение. Интонация. Словообразование. Морфология. Москва, 1980. 783 с. 
and the speaker's subconscious association, which establishes a semantic parallel between words that have different meanings. Unintentional confusion is based on the fact that the semantic side of the components of such pairs of single-root words is subjected to psychological transfer of direct meaning to the figurative. Synonymous alignment of words by analogy turns out to be a functional manifestation of paronymy.

Among the total number of lexical paronyms included in the adjective derivational series, the group of suffixal adjectives has been the most replenished in modern Russian in recent decades. They are modeled by suffixes such as $-H-/-л и \varepsilon_{-}, u j-/-c \kappa-(-е c \kappa),-u j-/-O B_{-} /-e b_{-},-u j-/-H_{-},-$ чam-/-OчH-, - am- $/-$ acm-. However, the most productive are adjectives with formants $-и ч е с к(и \check{u}) /-u ч н(b ы \check{u}),-е с к(u \check{u}) /-\mu($ bй $)$.

Words located within one word-building nest are included into wordbuilding paronyms, but different word-building rows and differing in lexical meaning, cf. couple перегородочный // перегородчатый:

(1) городить $\rightarrow$ перегородить $\rightarrow$ перегородка $\rightarrow$ перегородочный;

(2) городить $\rightarrow$ перегородить $\rightarrow$ перегородка $\rightarrow$ перегородчатый.

Derivative paronymy appears 1) as a consequence of derivational relations established between different meanings of polysemous words (кондукторный - кондукторский); 2) as a result of the development $\mathrm{V}$ appearance of derivational homonymy at the zero or $\mathrm{n}+1$ step of derivation (коренной - корневой, клеточный - клетчатый); 3) due to the direction of acts of derivation in different branches of the same word-formation nest, cf.: пес > псарня > псарный и пес > псарь > псарский; 4) through varying degrees of manifestation of signs (водный - водяной, болотистый болотнылй); 5) due to the preservation of the semantic relationship with obsolete words (ниточный - нитянылй).

Proceeding from the existence of morphological variation of a word in a language, I understand word-formation synonyms as a modification of the number and material composition of word-formation morphemes, which does not violate the identity of the word. The main features of wordformative synonyms are a) the identity of the root morpheme and b) semantic closeness, which is reflected in the synonymy of the wordformative formant and the same syntactic function of the derivative. The emergence and development of full or partial lexical-derivational synonymy is usually observed in that group of single-root paronymically related words of different derivational series that are included in one nest and are formed at the same or at different steps of derivation, cf. мелодия > мелодичный, мелодический, мистика > мистический, мистичный, хватать (хватить) > охватить/ обхватить >охваченный / обхваченный, чеканить >чеканка >чеканочный / чеканный; наследовать >наследный и наследовать >наследство > наследственный, сладкий >сладостный, 
шелк >шёлковый $и$ шёлк >шёлковый >шелковистый, etc. The consequence of word-formation synonymy is the formant selectivity of those who produce within the word-formation nest, that is, the formation of words according to one word-formation model.

Among word-formative synonyms of one word-formative nest, but different word-formative series, we single out (1) derivatives of one step of derivation (let's call them one-step equal derivatives), compare: безотлучный - неотлучный, and (2) derivatives of different steps of derivation (let's call them inter-step equal derivatives), compare: боевой боевитый, etc.

Equally derivative adjectives-synonyms are divided into two groups: отчетливы - четкий; and affix, cf.: безвозвратный - невозвратный, безутешный - неутешный, безотлучный - неотлучный; гармоничный гармонический, мелодичный - мелодический, басистый - басовитый; безопасный - неопасный (опасный).

Diversified derivational synonyms-adjectives are structurally, as well as equally derivative, unequal and represented by two groups: 1) one is monoform - the other is polyform, cf. великий - величавыци, бестактный нетактичный, бесталанный -неталантливый; 2) both synonyms are polymorphic, compare: антинаучныій - ненаучный; безызвестный неизвестный; невооруженный- безоружный.

Semantic differences between word-formation synonyms are mostly characterized by either a quantitative feature or the presence of negation. A quantitative sign is complicated by an emotional-evaluative connotation, cf.: здоровыци-здоровенный (vernacular).

\section{CONCLUSIONS}

The allocation of common features as a basis for postulating polysemy can be disputed in a number of cases, since not only their potential presence, but also their status in terms of word content is significant.

In linguistics, the concept of variability is twofold: (1) the characteristic of any linguistic variability, modification, which may be the result of evolution, the use of different linguistic means to denote similar or the same phenomena; (2) characterization of the way of existence and functioning of language units in synchrony.

In word-formation rows, we observe motivational connections between contracts. This is expressed (1) in the emergence of nodal connections, in which the main, motivating word of the next subordinate row (order) is located; (2) in parallel groups of derivatives, "double words" appear (synonyms, paronyms, derivational variants). This is explained by the fact that the word-formation system is based equally on formal and semantic relations. 
Distinguishing between external and internal motivational connections of single-root derivatives of different word-formation rows helps to reveal the semantic convergence of the components of their semantic structure and, in this regard, look at the process of the appearance of partial synonymy as a result of the intersection of word-formation rows.

The ratio of semantic features of the fields of derivational series creates a picture of the overlap or crossing of elementary fields with other fields. The intersection of elementary fields leads to the fact that some of them acquire "vague" boundaries, that is, in places of general semantic field, wordformation synonymy appears as a related phenomenon between paronymy and synonymy.

By analogy with lexical and derivational synonymy (homonymy), we distinguish between lexical and derivational paronyms. The consequence of derivational paronymy is derivational relations established between different meanings of polysemantic words, derivational homonymy at zero or $n+1$ derivation steps; varying degrees of manifestation of signs; maintaining a semantic link with obsolete words.

It has been determined that (1) if an indirect connection is established between the values of single-root derivatives through the vertex of the nest, or (2) if the values are directly related to different values of the generator and other single-root derivatives, then this leads to the appearance of partial or complete synonymy, that is, to the intersection of word-formation rows and the formation of a common semantic field (semantic-derivational field) at the point of their intersection.

If the general principle of differentiating morphological variants of one word and different (parallel) derivative words seems to be sufficient, then the theoretical criteria for differentiating derivational series have not yet been formed. In this I? see the prospect of further investigation of the problem raised.

\section{SUMMARY}

The study deals with the issues of describing the algorithm for the functioning of meanings within the framework of the semantic structure of adjectives in the Russian language, taking into account the invariant theory. The study noted that the instability of the content volume of many derived lexical units is supported by the phenomenon of paronymy - the mixing of words that have a similar sound, but differ semantically. The lack of a clear distinction between consonant units in speech often gives rise to situations of communication failures and misunderstanding. In this regard, the consistent differentiation of paronyms and synonyms is an important condition for the creation and perception of texts that are designed to ensure the accuracy and uniqueness of the translated meanings. This determines the relevance of the 
work. The object of the research is the vocabulary presented in the texts, which has full or partial similarities in the formal composition and differences in content. The subject of study is the causes and derivational mechanisms of the emergence of paronymy and its convergence with synonymy. The purpose of the study is to consider and describe the phenomenon of paronymic and synonymous word convergence. It was determined that paronyms and synonyms that function in the field of communication form privative oppositions, one of whose members (marked) is characterized by the presence of a certain differential feature, and the other (unmarked) by its absence.

\section{REFERENCES}

1. Ахманова О.С. Словарь лингвистических терминов [Текст]. Москва : Либриком, 2010. 576 с.

2. Бельчиков Ю.А. Словарь паронимов русского языка [Текст]/ Ю.А. Бельчиков, М.С. Панюшева. Москва : АСТ; Астрель, 2004. 458 с.

3. Бережан С.Г. Семантическая эквивалентность лексических единиц. Кишинев : Штиинца, 1973. 372 с.

4. Веракша Т.В. Лингвистическая природа паронимов русского языка : дис. ... д-ра филол. наук [Текст]: 10.02.01. Санкт-Петербург. 2000. 343 c.

5. Вишнякова О.В. Паронимия в русском языке [Текст]. Москва : Рус. язык, 1984. 382 с.

6. Воркачев С.Г. Из истории слов: лингвокультурный концепт [Текст]. Новое в когнитивной лингвистике. Кемерово : Изд-во КемГУ, 2006. C. 3-14.

7. Грінчишин Д.Г., Сербенська О.А. Словник паронімів української мови. Київ : Рад. школа, 1986. 222 с.

8. Голованова Е.И. Паронимия в научном тексте как проблема соотношения языковой формы и содержания [Текст]. Гуманитарный вектор. 2012. № 4 (32). С. 28-33.

9. Колесников Н.П. Паронимы и языковые стразы [Текст]. Филологический вестник Ростовского государственного университета. 2005. № 3. С. 384-390.

10. Красных В.И. Толковый словарь паронимов русского языка [Текст]. Москва : АСТ ; Астрель, 2003. 592 с.

11. Лазуткина Е.М. Публицистический стиль: новые черты [Текст]. Москва : Элпис, 2008. 79 с.

12. Лингвистический энциклопедический словарь [Текст] / под ред. В. Н. Ярцевой. Москва : Большая российская энциклопедия, 2002. 709 с. (ЛЭС). 
13. Русская грамматика : в 2 т. Москва : Наука, 1980. Т. 1 : Фонетика. Фонология. Ударение. Интонация. Словообразование. Морфология. Москва, 1980. 783 с.

14. Трубецкой Н.С. Основы фонологии / Пер. с нем. А.А. Холодовича; Под ред. С.Д. Кацнельсона; Послесл. А.А. Реформатского; Вступ. ст. Л.А. Касаткина. 2-е изд. Москва : Аспект-Пресс, 2000. 352 с.

Information about the author: Shepel Yu. A., Doctor of Philology, Professor, Academician National Academy of Higher Education Sciences of Ukraine, Professor at the Department of Translation and Linguistic Training of Foreigners Oles Honchar Dnipro National University 72, Gagarin Avenue, Dnipro, 49010, Ukraine 